Int. J. Dev. Biol. 49: 173-180 (2005)

doi: $10.1387 / \mathrm{ijdb} .041951 \mathrm{rl}$

\title{
Endothelin receptor $B$ is required for the expansion of melanocyte precursors and malignant melanoma
}

\author{
RONIT LAHAV* \\ Institut Universitaire de Pathologie, Lausanne, Switzerland
}

\begin{abstract}
Since embryonic development and tumorigenesis share common characteristics, studying the role of genes during development can identify molecules that have similar functions in both processes. C-kit and Endothelin receptor B (EDNRB or ETRB) are crucial for melanocyte development in mice and humans but have different functions. While c-kit is needed for survival throughout development until late stages of differentiation in the skin, EDNRB promotes early expansion and migration while delaying the differentiation of melanocyte precursors. Transformation of normal melanocytes to melanoma cells is often associated with gradual loss of differentiation and the gain of high autonomous capacity to proliferate. In accordance with their different roles, c-kit expression is gradually lost during melanoma transformation, while that of EDNRB is greatly enhanced and can serve as a marker of melanoma progression. Inhibiting EDNRB function with a specific antagonist (BQ788) in human melanoma cell lines results in inhibition of growth often associated with induced differentiation indicating that, during melanoma transformation also, the function of EDNRB is to promote growth. EDNRB function does not seem to be essential in the adult, as BQ788 administration to healthy people does not result in major effects. This is probably why BQ788 can specifically inhibit the growth of xenograft human melanoma tumors in nude mice, in a way resembling spontaneous human melanoma regression and why it could serve as a potential therapeutic agent for melanoma.
\end{abstract}

KEY WORDS: endothelin receptor B, melanocyte, development, melanoma, BQ788

Spots in mice and man

A powerful tool in identifying genes that are important for the development of pigment cells is the characterization of genetic traits that result in white spots due to the lack of melanocytes in the skin. In mice, there are mutations affecting the embryonic development of integumental melanocytes, which typically have no effect on the eyes, but cause a local or global loss of skin pigmentation. These loci affect the cells early in their developmental history and interfere with their ability to migrate and colonize the skin. These strains are called spotting mutants, in which the degree of pigmentation varies from white spots to complete white coat color (and black eye), the latter considered as essentially one big spot (Bennett, 1993). Some of the genes responsible for spotting mutations in mice have a similar function during development of melanocytes in humans since, when mutated, they also result in white areas of the skin in which melanocytes are absent as summarized in Table 1. This review will focus on two ligand receptor systems: c-kit receptor and its ligand Steel or Stem Cell Factor (SCF) and Endothelin receptor B (EDNRB) and its ligand Endothelin 3 (EDN3).

\section{Different spots - different functions}

\section{The c-kit - Steel molecular system}

Kit ${ }^{W}$ or $\mathrm{Mgf}^{\mathrm{Sl}}$ heterozygous mice have scattered or diluted spots

In the spotting category, two loci with pleiotropic effects on the development of melanocytes, hematopoietic and germ cell lineages have attracted the interest of embryologists for decades. These are: Dominant White spotting (Kit $\left.{ }^{W}\right)$, identified by Little (Little, 1915) and Stee/ $\left(M g \mathcal{F}^{\mathcal{S}}\right)$, first described by Sarvella and Russell (1956) (for reviews see Russell, 1979; Silvers WK, 1979).

By definition, pigmentation is affected in all of the animals heterozygous for any allele at the $\mathrm{Kit}^{W}$ locus, although the extent of white spotting can vary. The characteristic spotting pattern of Kit $^{W}$ heterozygotes is scattered, with no discrete boundaries between pigmented and non-pigmented regions (Geissler et al.,

Abbreviations used in this paper: $\mathrm{BQ} 788$, an endothelin receptor $\mathrm{B}$ antagonist; EDN3, endothelin 3; EDNRB, endothelin receptor B; MITF, microphtalmiaassociated transcription factor; SCF, stem cell factor. 
1981). $M g f^{\mathcal{S} /}$ heterozygotes have a slight dilution of the coat color (Stee/ received its name from this fact) as well as spotting, white blaze on the forehead, white belt spot and unpigmented feet and tail tip (Sarvella and Russell, 1956). Viable homozygous of both strains are blacked eye and completely white (Markert and Silvers, 1956; Bennett, 1956). In humans, a high correlation was found between c-kit mutations and piebald patients who suffer from absence of pigmentation from the forehead, eyebrows and chin and of the ventral chest, abdomen and extremities (Fleischman et al., 1991; Spritz et al., 1992; Dippel et al., 1995; Ezoe et al., 1995)

The time at which melanoblasts development diverges from normal in mice carrying $\mathrm{Kit}^{W}$ or $\mathrm{Mgf}^{\mathcal{S} /}$ mutations was not known. Apparently, melanoblasts from $K_{i} t^{W}$ homozygotes do not reach the skin since the epidermis is devoid of melanocyte precursors already at 14 days of gestation (Mayer, 1970). Chimeric association of dermal-epidermal tissues from $\mathrm{Kit}^{W}$ and wild type mice of different embryonic stages led to the suggestion that in $\mathrm{Kit}^{W}$ the melanocyte precursors are «marginally viable». They are gradually lost during different points in their developmental pathway namely, from the establishment of the line, during the migratory process, colonization of the hair follicles and even after melanin synthesis has occurred (Gordon, 1977; Mayer, 1979).

\section{C-kit is needed during migration, colonization and population of melanoblasts in the skin}

The suggestion that Kit ${ }^{W}$ melanoblasts are affected at different stages during development until E14 is supported by in situ analysis of the gene product of Kit : c-kit (Geissler et al., 1988; Chabot et al., 1988) and its ligand SCF, the gene encoded by the Steel locus (Martin et al., 1990; Zsebo et al., 1990; Copeland et al., 1990; Williams et al., 1990; Huang et al., 1990). The first few cells expressing $c$-kit mRNA are detected dorsal to the somites within the migratory pathway of the neural crest cells at E9.5-E10, approximately 24-36 $\mathrm{h}$ after crest cells emerge from the neural tube. Expression of c-kitmRNA on presumptive melanoblasts persists thereafter (Manova and Bachvarova, 1991; Yoshida et al., 1996).

In the avian system we could define the exact stage by which neural crest melanocyte precursors start expressing $c$-kit, by using in situ hybridization in combination with the quail-chick chimera system (Teillet and Le Douarin, 1970; Le Douarin and Kalcheim, 1999). After grafting a quail neural primordium into a chick host,

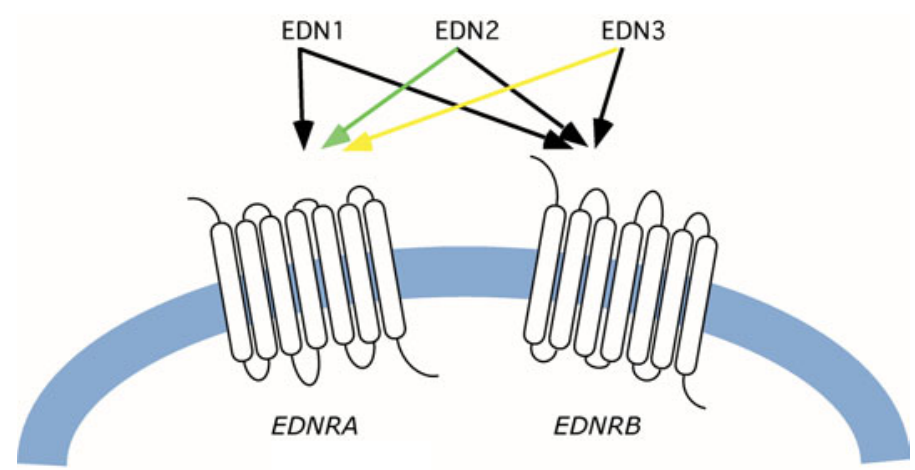

Fig. 1. Schematic representation of the endothelins and their interactions with endothelin receptors. EDNRA binds preferentially EDN1, whereas EDNRB binds the three endothelins with similar affinities. neural crest cells could be followed during the entire migration process. We thus found that neural crest cells migrating along the dorsolateral pathway express $c$-kit as early as $E 4$, that is about two days after the first neural crest cells have left the neural tube (Lecoin et al., 1995). These results show that $c$-kit positive cells appear a day or two after neural crest cells start their migration and persist during development.

In mice, using c-kit as a marker for melanoblasts, their progression pattern during different developmental stages could be documented. Analysis of adult $\mathrm{Kit}^{W}$ heterozygous mice coat color showed that the pattern of melanocyte distribution corresponds to the one observed at E13.5-E14.5 in wild type embryos, meaning that, in $\mathrm{Kit}^{W}$ mice, melanocytes developed only until that stage (Review: Yoshida et al., 2001).

Functional studies showed that there is a critical requirement for c-kit at E13.5 (Nishikawa et al., 1991) but the lack of c-kit signaling affects melanoblast migration even earlier starting at E11 (Steel et al., 1992)). In addition c-kit was also shown to be required for melanocyte activation in the hair cycle that occurs throughout life (Nishikawa et al., 1991). It seemed, indeed, as was suggested before that $\mathrm{c}$-kit and SCF are needed to sustain melanoblast development in different stages of embryogenesis starting at E10 until E13.5 and also later on during adulthood.

\section{C-kit and SCF are required for melanoblasts survival and differentiation}

In order to define the function of SCF, we studied the effect of chicken recombinant SCF on the development of melanocytes from quail neural crest cells in vitro. We showed that SCF mainly promotes survival of neural crest cells and stimulates the differentiation rate of melanocytic precursors (Lahav et al., 1994). These results are in agreement with those showing that SCF is required for survival of murine melanocytes and for their enhanced differentiation in culture (Morrison-Graham and Weston, 1993; Murphy et al., 1992). Taken with the expression pattern, we concluded, similarly to studies carried out in mice, that SCF and c-kit are required mainly for survival and differentiation of melanocyte precursors during migration, colonization and population of the skin.

\section{The Endothelin System}

\section{In Ednrb ${ }^{S-l}$ and Edn3 ${ }^{\text {ss }}$ mice, spotted areas have defined margins}

Piebald is a recessive mutation known in the mouse since a long time. Homozygotes have dark eyes and show irregular white spotting of the coat, especially on the belly, sides and back. The borders between white and pigmented areas are sharply defined. The white areas of the coat completely lack melanocytes. There is a reduction in the number of melanocytes in the choroid layer of the eye. In addition, homozygotes may develop megacolon that is always associated with lack of ganglion cells in the distal portion of the colon. Mice with a more severe mutation at the piebald locus, piebald lethal ( $\left.E d n r b^{S-}\right)$, have dark eyes and an almost completely white coat with pigmented hair restricted to small areas on the head and base of the tail. All Ednrb $b^{S-/}$ homozygotes develop megacolon with lack of enteric ganglion cells in the posterior end of the colon. They usually die at about two weeks of age, but some live a year or more and may breed (Lyon and Searle, 1990).

Another recessive mutation that resembles piebald mice is Lethal spotting $\left(E d n 3^{\prime s}\right)$. Lethal spotting mice usually die in the third 
week of life, however some survive and are fertile. Homozygotes have considerable white spotting and megacolon. Like in piebald, the most distal portion of the bowel is aganglionic in these mice.

The breakthrough in the study of the developmental abnormalities caused by $E d n r b^{S-1}$ and $E d n 3^{s}$ has been the identification of the genetic defects responsible for these mutations and the discovery that a related defect is also present in a subset of patients with Hirschsprung's disease (Puffenberger et al., 1994; Hosoda et al., 1994; Baynash et al., 1994) for review see (McCallion and Chakravarti, 2001). These abnormalities are in genes encoding EDNRB or its ligand EDN3.

The endothelins 1, 2 and 3 (EDN1, EDN2 and EDN3) are a family of 21 amino acid peptides that activate one or both of the two heptahelical, G-protein-coupled endothelin receptors, A and B (EDNRA and EDNRB). EDNRA exhibits different affinities for endothelin peptides with a potency rank order of EDN1>EDN2>>EDN3 (Yanagisawa, 1994). EDNRB accepts all three peptides equally (Sakurai et al., 1990), as shown in Fig. 1.

\section{$E D N R B$ is needed before the onset of migration}

Murine and avian neural crest cells start expressing EDNRB at the premigratory stage (Reid et al., 1996; Nataf et al., 1996). Avian EDNRB is detected from E2 when crest cells become individualized in the dorsal neural primordium, which is about two days before the onset of c-kit expression. Avians have a second receptor, EDNRB2, which later on is only expressed by melanoblast and melanocytes (Lecoin et al., 1998). Both receptors seem to be important for melanocyte development since stimulation of cultured neural crest cells with EDN3 results in an initial increase in the expression of EDNRB that is followed by enhanced expression EDNRB2 (Lahav et al., 1998).

EDNRB also affects the melanogenic lineage at earlier developmental stages than c-kit. Murine melanoblasts were shown to be affected in Ednrb ${ }^{S-/}$ mutants before they express melanogenic markers (Pavan and Tilghman, 1994) and not after as was shown for c-kit mutants. In addition analysis of the coat pigmentation pattern of EDNRB deficient mice shows that it resembles the distribution pattern of E10 embryos (Yoshida etal., 2001), meaning that, in these mice, melanocyte precursors progressed in their development only until this stage and not until E13.5 as in c-kit deficient mice. The period between $\mathrm{E} 10$ and $\mathrm{E} 12.5$ was shown to be critical for melanoblasts development in mice with conditional expression of EDNRB (Shin et al., 1999). The authors concluded that EDNRB plays a critical role in initiating emigration of melanoblasts from the neural tube and surviving the transitional period before migration begins. These data are consistent with an early reduction in the number of presumptive melanoblasts in EDNRB deficient mice and suggest that the receptor is required at or immediately before melanoblast proliferation and migration.

Yoshida et al., also suggest that comparison of EDNRB and EDN3 mutant mice indicate that endothelin signaling may be required again for melanocyte proliferation in the epidermis (Yoshida et al., 1996).

\section{EDNRB and EDN3 are needed for early expansion of melanocyte precursors}

We used an in vitro assay system to study the role of EDN3 during the development of melanogenic cells from the neural crest cell population (Lahav et al., 1996). Addition of EDN3 to quail

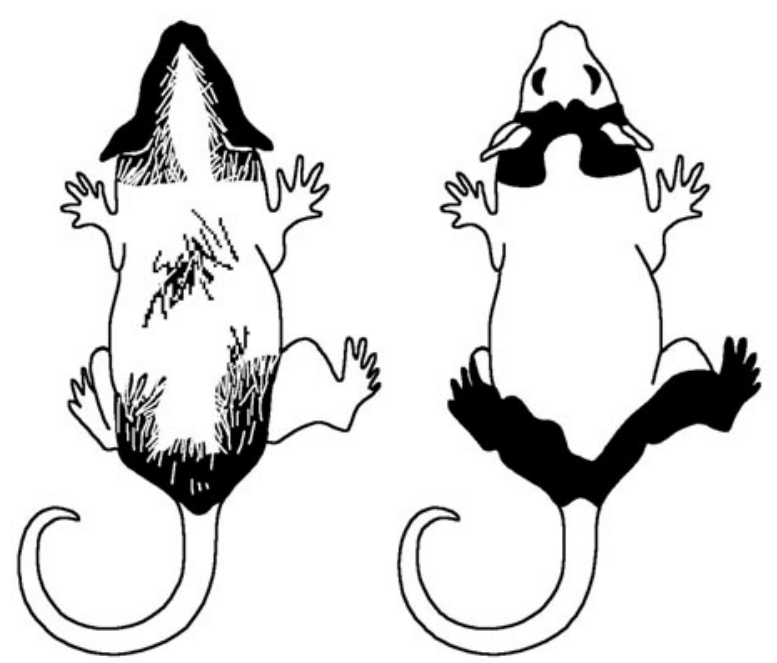

Fig. 2. Characteristic differences in spotting patterns between a mouse carrying a mutation in the c-kit receptor (left), with intermingled white and black hair and (right) a mouse with an EDNRB deficiency with sharp margins between white and black regions.

neural crest cultures strikingly increased the number of melanocytes. Examining the evolution of such cultures revealed that this was a result of a massive increase in proliferation accompanied by an initial delay of differentiation. Repeating these experiments in defined medium conditions showed clearly that the functions that could be attributed to EDN3 alone are indeed enhancement of proliferation and inhibition of differentiation. These results are in agreement with those of Sviderskaya et al. (1998) showing that primary melanoblast cultures taken from EDNRB mutant mice were differentiation-deficient compared with wild-type.

We could also show that EDN3 affects neural crest precursors before they are committed to the melanocytic lineage. Clonal cultures showed that EDN3 expands the common precursors of melanocytes and glia cells (Lahav et al., 1998). Moreover addition of EDN3 to melanocyte or glia cultures can revert the cells to the earlier common precursor stage resulting in the appearance of both melanocytes and glia from clonal population of either melanocytes or glia (Dupin et al., 2000; Dupin and Le Douarin, 2003; Dupin et al., 2003).

\section{The big spot picture}

Some melanoblasts die before they migrate, others die after

Taken together it seems that the EDNRB/EDN3 receptorsystem is needed to promote early precursor proliferation before or coincident with neural crest migration while the c-kit/SCF system is needed for survival and differentiation of melanocyte precursors while they colonize the embryonic skin.

The functional difference between these two molecular systems is also reflected in the different spotting patterns between $E d n r b^{S-}$ ' and KitW mice.

To explain spotting, Mintz proposed that the whole coat pigmentation derives from 34 melanoblasts according to the maximum number of territories that she could observe in aggregation chimeras (Mintz, 1967). Each melanoblast migrates and proliferates along the dorso-ventral axis to populate a strip-like territory. Spots 
occur when the descendants of certain clones die since their progenitors were «preprogrammed» to die. Since their death happens relatively late, other clones cannot expand to their territory and an unpigmented region occurs.

Schaible suggested that there are 14 melanoblasts, each migrating to a center of a territory and expanding. Spotting occurs when the early melanoblasts die or cannot proliferate (Schaible, 1969). Other clones cannot expand to cover the depigmented area since this process is limited in time. Clones can expand before the tissue environment differentiates to the point that it restricts pigment cell migration.

Our data suggest that between the stages at which melanoblasts require EDNRB and c-kit function, a large expansion in population size occurs. This is supported by experiments showing that murine EDNRB function is required before E10.5. At that stage, very few melanoblasts are detected in wild type mice as suggested by Mintz and Schaible (Pavan and Tilghman, 1994). By the time that c-kit is first needed (E11.5) the dermis is seeded with numerous cells identified as melanoblasts (Wehrle-Haller and Weston, 1995).

Taken together, spotting in Ednrb $b^{S-1}$ and Edn $3^{S /}$ might occur according to the explanation provided by Schaible since the precursors are probably affected before they expand. In contrast in $\mathrm{Kit}^{W}$ or $M g f^{\mathcal{S}}$ the mechanisms that lead to spotting resemble more those described by Mintz where melanoblasts that are destined to die (i.e. carry a mutation) first expand. These differences might also account for the differences in the nature of spots. In $E d n r b^{S-1}$ and $E d n 3^{S /}$ the spots have sharp margins since the precursors were eliminated early resulting in the absence of all their descendants in a certain area of the skin (Fig. 2 right). In contrast, in $\mathrm{Kit}^{W}$ or $\mathrm{Mg}{ }^{\mathcal{S}}$ melanoblasts are affected relatively late. At this stage many melanoblasts are found in the dermis. Partial elimination of melanoblasts would result in small distances among pigmented and unpigmented hair (Fig. 2 left). This pattern is well

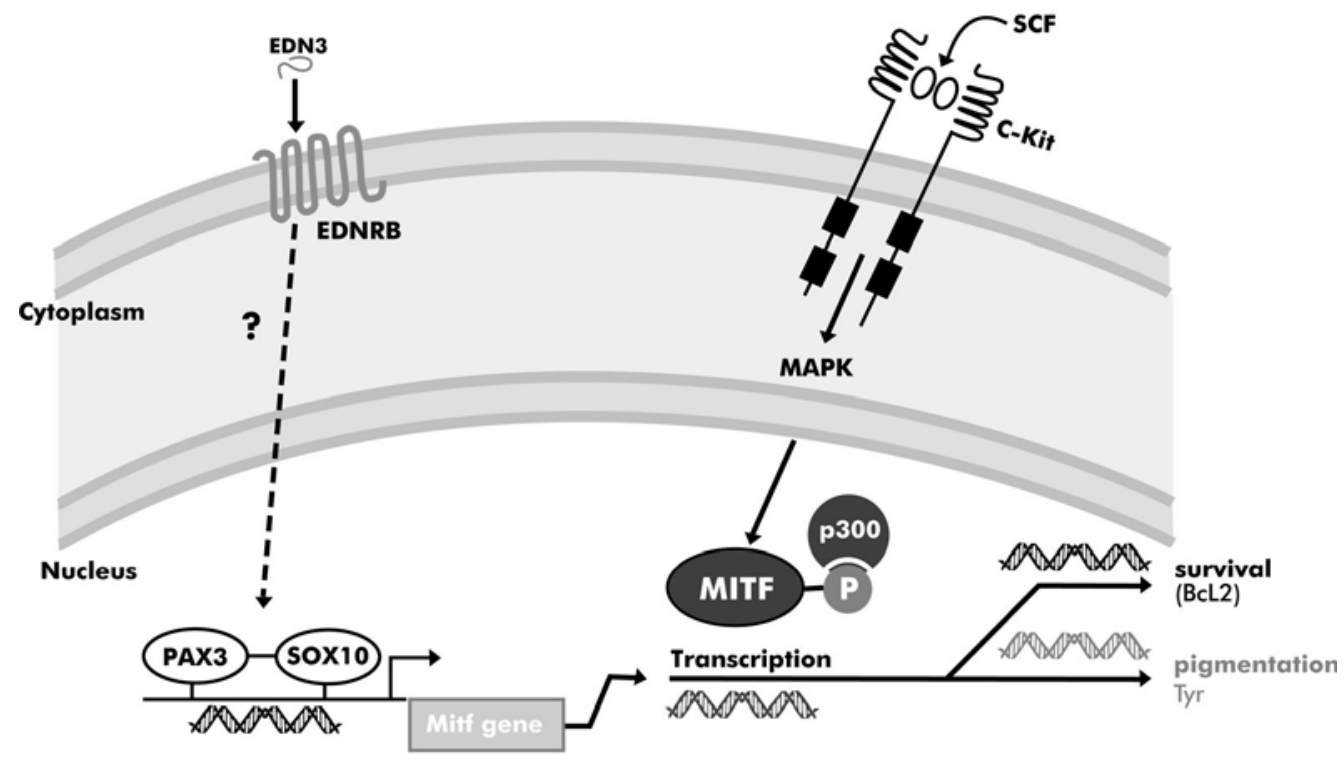

Fig. 3. c-kit can promote survival and differentiation by activating the transcriptional activity of MITF which will induce the expression of BCL2 and Tyrosinase. One way by which MITF transcription can be regulated is by SOX10 and Pax3. EDNRB interaction in this pathway is suggested by the fact that mutations in both EDNRB and SOX10 cause the same syndrome in humans, although the mechanism is unknown. represented in mice that were treated relatively late (E13.5E14.5) with an antibody which antagonizes c-kit function (Nishikawa et al., 1991).

Interestingly melanoblasts show an uneven distribution along the murine neural axis. Many more melanocyte precursors are found in the head and tail as compared to the trunk region (until E15.5) consistent with the areas that are often pigmented in spotted mice (Pavan and Tilghman, 1994; Wehrle-Haller and Weston, 1995). This could explain why pigmentation is more often retained in the head and tail regions.

\section{Spot signaling: $C$-kit can promotes survival and differentiation by activating MITF. EDNRB interactions are not yet known}

One of the molecular pathways by which c-kit and SCF affect melanocyte development involves genes with known effects on pigmentation in mice and man, like: MIFT, SOX10 and Pax3 (see table 1) (Review: Rawls etal., 2001). C-kit can affect differentiation and survival of melanocyte precursors by inducing MITF phosphorylation and transcriptional activity (fig. 3). MITF (microphtalmia-associated transcription factor) is a basic helixloop-helix/leucine zipper protein that is considered as a melanocytic key regulator since its overexpression can cause cells to adopt melanocyte characteristics (Tachibana et al., 1996; Lister et al., 1999). MITF has been shown to induce the transcription of pigmentation genes like tyrosinase and survival factors like BCL2 (Hou et al., 2000; McGill et al., 2002). In this model, a downstream component of the kit-signaling pathway, MAPK, phosphorylates MITF, thereby creating a binding site for the transcriptional coactivator p300 (Sato et al., 1997; Hemesath et al., 1998; Price et al., 1998). This transcriptional activation will stimulate MITF before its rapid ubiquitin-mediated degradation (Wu et al., 2000).

EDNRB interactions with MITF, Pax3 and SOX10 are not well understood in spite of the fact that mutations in EDNRB and SOX10 cause exactly the same syndrome in humans and mice (Southard-Smith et al., 1998; Potterf et al., 2000). Recently, SOX10 was shown to have multiple binding sites on an EDNRB enhancer which serve to upregulate EDNRB expression in the enteric system (Zhu et al., 2004). In addition, EDNRB inhibition causes down regulation of its own expression in melanomas, suggesting that EDNRB signaling can enhance its own expression (Lahav et al., 2004). Taken together, since EDNRB is needed in order to expand melanocyte-glia precursors while delaying their differentiation, one could suggest the following sequence of events: the EDNRB signaling pathway functions first, amplifying itself with the continuous presence of its ligand EDN3 and the transcription factor SOX10. Once enough precursors are produced, MITF 
transcription is transiently stabilized by c-kit to allow the gradual differentiation and enhanced survival of melanocyte precursors.

\section{Spots and melanoma}

\section{From no melanocytes to too many}

The temporal and functional differences between the c-kit/SCF and EDNRB/EDN3 receptor-ligand systems in their effect on melanocyte precursors seems to be reflected also in the situation of melanocyte malignancy. C-kit expression is normally reduced or absent in melanoma cell lines and it seems therefore, that a reduction in c-kit gene expression either promotes or is a consequence of transformation of melanocytes (Lassam and Bickford, 1992; Zakut et al., 1993) for review (Nyormoi and BarEli, 2003). This finding correlates well with loss of differentiation function characterizing the malignant phenotype.

In contrast melanoma cells acquire a high capacity to proliferate (Review: Halaban etal., 2000) since EDNRB promotes proliferation while inhibiting differentiation, it is not surprising that its expression is highly enhanced in cutaneous melanoma (Loftus et al., 1999). In a study that examined gene expression profiling of 6,971 genes in 31 human melanoma samples from biopsies or tumor cell cultures, a general increase of EDNRB expression was observed (Bittner et al., 2000). A similar observation was made in another study of gene expression patterns in human cancer cell lines. Here again, all the melanoma samples tested showed overexpression of EDNRB (Ross et al., 2000). EDNRB was also found to be a melanoma progression marker since immunohistochemostry on paraffin-embedded tissue sections of 159 human melanoma cases revealed an increase of EDNRB expression as melanoma progressed to metastatic disease (Demunter et al., 2001).

These findings suggest that EDNRB activation contributes to melanoma development and progression. In support of this view
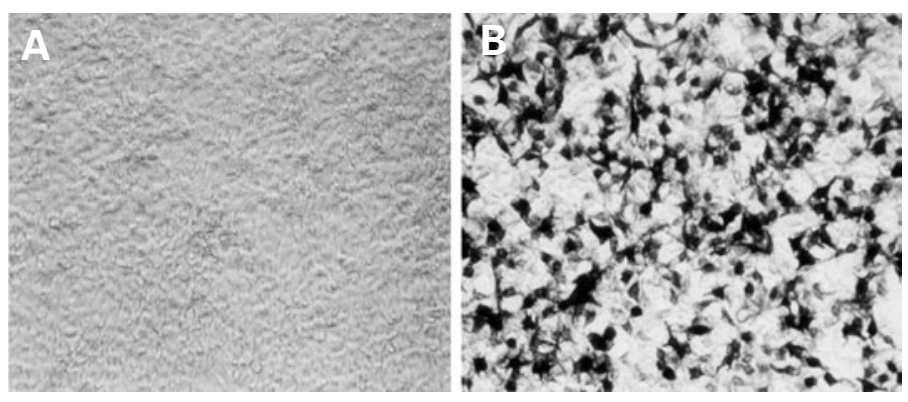

Fig. 4. Effect of the EDNRB antagonist $B Q 788$ on neural crest cultures treated with EDN3. Neural crest cultures were treated with EDN3 for 5 days during which there is a massive increase in cell number and inhibition of differentiation (A). Administration of BQ788 results in decrease in cell number and induced differentiation as can be seen by the appearance of pigmented cells (B).

is the finding that EDN1 is secreted by keratinocytes in the skin in response to ultraviolet irradiation (Imokawa et al., 1992; Ahn et al., 1998), which is known to be the most commoncausative factor of the disease (Atillasoy et al., 1998). Moreover, UV-induction of keratinocyte EDN1 down regulates E-cadherin in melanocytes and melanoma (Jamal and Schneider, 2002). Down regulation of E-cadherin expression is typical for melanomas and serves to enhance their invasive capability (Hsu et al., 2000).

\section{Treating melanoma}

In order to assess the functional importance of EDNRB for melanoma progression, we used a specific antagonist of the receptor: BQ788 (Ishikawa et al., 1994). BQ788 is a highly selective inhibitor of EDNRB that was developed as a potential drug for cardiovascular disorders since endothelins serve in the adult as potent vasoconstrictors. However, these effects are predominantly mediated by EDNRA (for review: Luscher and

TABLE 1

SPOTTING IN MAN AND MICE

\begin{tabular}{|c|c|c|c|c|}
\hline Gene & Human disease & Symptoms & Mouse mutant & Phenotype \\
\hline \multicolumn{5}{|l|}{$P A X 3$} \\
\hline $\begin{array}{l}\text { (Paired and homeobox } \\
\text { domain transcription factor) }\end{array}$ & WS-1, 3 & $\begin{array}{l}\text { Wide bridge of the nose owing to lateral } \\
\text { displacement of the inner canthus of each eye, } \\
\text { pigmentary disturbance and cochlear deafness. } \\
\text { In WS-3 also upper-limb defects. }\end{array}$ & $P a x 3^{S p}:$ Splotch & $\begin{array}{l}\text { Whit spots and neural } \\
\text { tube defects. }\end{array}$ \\
\hline \multicolumn{5}{|l|}{ SoX 10} \\
\hline $\begin{array}{l}\text { (SRY-like HMG box } \\
\text { transcription factor) }\end{array}$ & WS-4 & $\begin{array}{l}\text { Pigmentary disturbance, cochlear deafness } \\
\text { and megacolon. }\end{array}$ & $\begin{array}{l}\text { Sox } 10^{\text {Dom }} \text { : } \\
\text { Dominant megacolon }\end{array}$ & White spots and megacolon. \\
\hline \multicolumn{5}{|l|}{ EDNRB } \\
\hline (7 TM G coupled receptor) & $\begin{array}{l}\text { Waardenburg syndrome, } \\
\text { type IV (WS-4) and } \\
\text { ABCD syndrome }\end{array}$ & $\begin{array}{l}\text { Pigmentary disturbance, cochlear deafness } \\
\text { and megacolon. } \\
\text { Albinism, black lock, cell migration disorder } \\
\text { of the neurocytes of the gut and cochlear deafness }\end{array}$ & $\begin{array}{l}\text { Ednrb }{ }^{s-1} \text { : Piebald } \\
\text { (spotting) }\end{array}$ & White spotting and megacolon \\
\hline \multicolumn{5}{|c|}{ - } \\
\hline $\begin{array}{l}\text { (Helix-loop-helix-leucine- } \\
\text { zipper transcription factor) }\end{array}$ & WS-2a & $\begin{array}{l}\text { Pigmentary disturbance and high frequency of } \\
\text { cochlear deafness. }\end{array}$ & $\begin{array}{l}\text { Mitf }{ }^{M i W h}: \\
\text { Microphthalmia }\end{array}$ & $\begin{array}{l}\text { Whit coat, abnormal eye, } \\
\text { osteoporosis, hematopoietic } \\
\text { and neural crest defects. }\end{array}$ \\
\hline \multicolumn{5}{|r|}{ 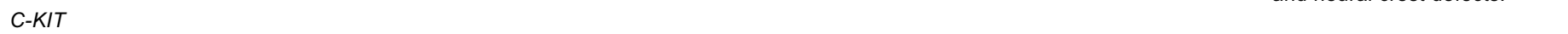 } \\
\hline (Tyrosine kinase receptor) & Piebaldism & $\begin{array}{l}\text { Absence of pigmentation from forehead, } \\
\text { eyebrows and chin and of the ventral chest, } \\
\text { abdomen and extremities. Often associated } \\
\text { with cochlear deafness }\end{array}$ & $\begin{array}{l}\text { Kit }{ }^{W}: \text { Dominant } \\
\text { (white) spotting }\end{array}$ & White coat, sterility and anemia \\
\hline
\end{tabular}



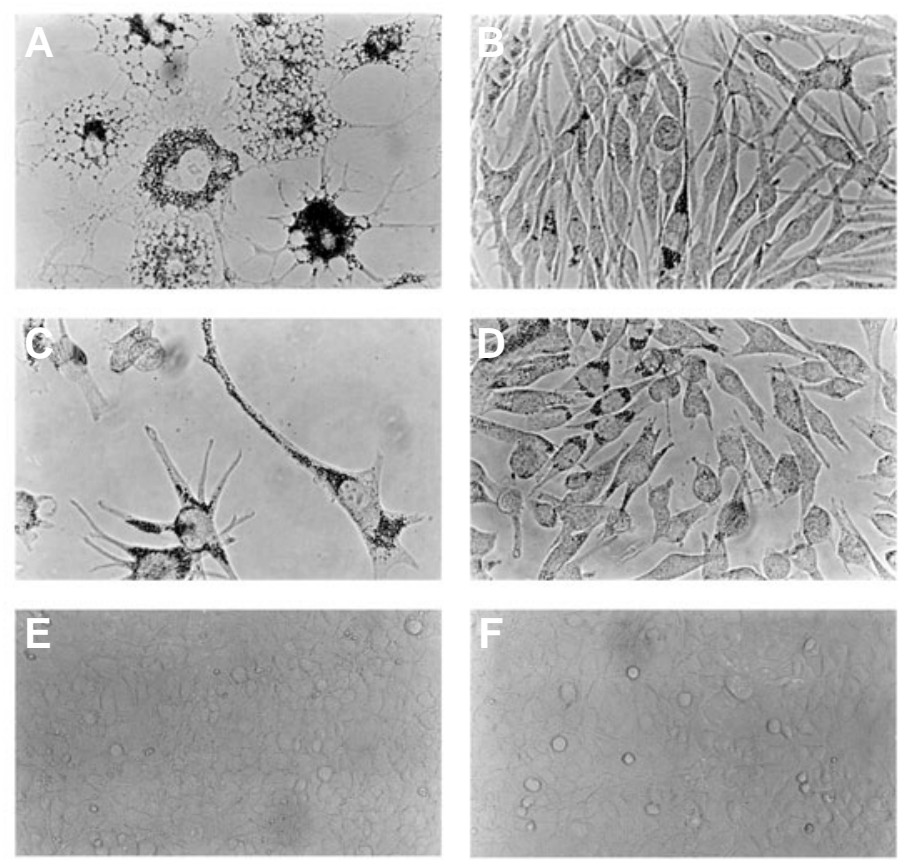

Fig. 5. Effects of the EDNRB antagonist BO788 on human melanoma cells. Human melanoma cells SK-MEL-28 (B) and SK-MEL-5 (D) loose viability and enhance differentiation when treated with $B Q 788(\mathbf{A}, \mathbf{C})$. Human kidney cells (F) do not seem to be affected by BQ788 (E).

Barton, 2000)). This is probably why administration of BQ788 to healthy volunteers left their blood pressure unaffected (Strachan et al., 1999).

BQ788 effects were first tested on neural crest cultures treated with EDN3 for 5 days. At this stage the cultures display all the characteristic effects of EDNRB function, namely high increase in cell number and inhibition of differentiation as can be seen in Fig. 4A. Addition of BQ788 could reduce cell number and increase differentiation as demonstrated by the development of pigment in these cultures (Fig. 4B).

The appearance of EDN3 treated neural crest cultures (Fig. 4A), where cells are not contact inhibited, highly proliferative and not differentiated, made us think that the endothelin system might have a role in transformation of normal cells to melanoma.

In order to check this hypothesis, two human melanoma cell lines, SK-MEL-28 and SK-MEL-5 were used, together with a human kidney cell line, HEK-293, as a control. The melanoma cell lines have a spindle morphology, are densely populated and slightly pigmented (Fig. 5B,D). However in the presence of BQ788, the cells flatten significantly on the dish surface and show a major increase in pigmentation (Fig. $5 \mathrm{~A}, \mathrm{C}$ ). Cell numbers reduce dramatically and treatment of SK-MEL- 5 cells also results in a dendritic phenotype similar to that observed in normal, mature melanocytes (Fig. 5C). In contrast, treatment of kidney 293 cells with BQ788 does not result in any morphological change demonstrating that this inhibitor does not cause such effects in all cell types (Fig. 5 E,F). Seven different melanoma cell lines significantly reduce their viability when treated with $B Q 788$, in contrast to kidney cells which present a slight increase in viability demonstrating that BQ788 does not exert a general toxic effect (Lahav et al., 1999).
To test BQ788 effectiveness in inhibiting tumor growth in vivo, human melanoma cell lines were induced to grow as subcutaneous tumors in nude mice. About two weeks later when the tumors were growing stadily, the mice were divided into two groups receiving either vehicle or BQ788 injected daily into the tumor. During 10 days of treatment a significant and reproducible inhibition of tumor growth is observed in the BQ788 treated groups of mice. Systemic administration of the drug under the same conditions results in a significant reduction in tumor growth, with however a grater variability in the response of the treated group. Further analyses show that the treated mice can be divided into two groups, half with significant but moderate inhibition of tumor growth and the others with an almost complete shrinkage of the tumors. One of the reasons for the inhibition of tumor growth is enhanced apoptosis as revealed by a general increase in tunnel staining in tumor sections (Lahav et al., 1999).

Recently, our observation has been corroborated with a different EDNRB antagonist showing that EDNRB inhibition is effective in inhibiting human melanoma tumor growth in nude mice (Bagnato etal., 2004). Moreover, using BQ788, the authors could show that EDNRB mediates many known molecular events characteristic of melanoma progression (Bagnato et al., 2004).

As melanoma is of more metastatic grade, it shows higher EDNRB expression and as a result is more sensitive to EDNRB inhibition resulting in increased apoptosis. This suggests that EDNRB inhibition would be most effective against metastatic melanoma. EDNRB expression levels are also important for melanoma survival. Specific reduction in RNA and protein levels of EDNRB using RNAi leads to reduced melanoma viability (Lahav et al., 2004).

Studying the mechanisms by which EDNRB induces apoptosis in melanoma has revealed the participation of two genes, BCL$2 \mathrm{~A} 1$ and PARP-3, with known functions in survival and apoptosis. We show that EDNRB inhibition results in down regulation of $B C L-$ 2A1 and PARP-3 before the cells start dying, and levels of reduction in their expression directly correlate with the levels of apoptosis induced (Lahav et al., 2004). Therefore it seems that advanced, metastatic melanoma expresses higher levels of EDNRB and inhibition of EDNRB function leads to reduced expression levels of EDNRB, BCL-2A1 and PARP-3 and subsequently to apoptosis.

Interestingly, EDNRB inhibition up-regulates VEGF and other angiogenic factors resulting in increased appearance of blood vessels in BQ788 treated tumors with inhibited growth (Lahav et al., 2004). This is a feature which fits well with the pathology of spontaneously regressing human melanomas that are characterized by increased vascularity (Weedon, 2002). Thus, EDNRB inhibition may also be the driving force of human melanoma regression highlighting even more the therapeutic potential of EDNRB inhibition for melanoma.

\section{References}

AHN, G.Y., BUTT, K.I., JINDO, T., YAGUCHI, H., TSUBOI, R. and OGAWA, H. (1998). The expression of endothelin-1 and its binding sites in mouse skin increased after ultraviolet B irradiation or local injection of tumor necrosis factor alpha. $J$. Dermatol. 25: 78-84.

ATILLASOY, E.S., SEYKORA, J.T., SOBALLE, P.W., ELENITSAS, R., NESBIT, M. ELDER, D.E., MONTONE, K.T., SAUTER, E. and HERLYN,M. (1998). UVB induces atypical melanocytic lesions and melanoma in human skin. Am. J. Pathol. 152: 1179-1186. 
BAGNATO, A., ROSANO, L., SPINELLA, F., DI, C.V., TECCE R and NATALI, P.G. (2004). Endothelin $B$ receptor blockade inhibits dynamics of cell interactions and communications in melanoma cell progression. Cancer Res. 64: 14361443.

BAYNASH, A.G., HOSODA, K., GIAID, A., RICHARDSON, J.A., EMOTO, N., HAMMER,R.E. and YANAGISAWA,M. (1994). Interaction of endothelin-3 with endothelin-B receptor is essential for development of epidermal melanocytes and enteric neurons. Cel/ 79, 1277-1285.

BENNETT, D. (1956). Developmental analysis of a mutation with pleiotropic effects in the mouse. J. Morphol. 98: 199.

BENNETT, D.C. (1993). Genetics, development and malignancy of melanocytes. Int. Rev. Cytol. 146: 191-260.

BITTNER, M., MELTZER, P., CHEN, Y., JIANG, Y., SEFTOR, E., HENDRIX, M., RADMACHER, M., SIMON, R., YAKHINI, Z., BEN DOR, A., SAMPAS, N., DOUGHERTY, E., WANG, E., MARINCOLA, F., GOODEN, C., LUEDERS, J., GLATFELTER, A., POLLOCK, P., CARPTEN, J., GILLANDERS,E., LEJA, D., DIETRICH, K., BEAUDRY, C., BERENS, M., ALBERTS, D. AND SONDAK, V. (2000). Molecular classification of cutaneous malignant melanoma by gene expression profiling. Nature 406: 536-540.

CHABOT, B., STEPHENSON, D.A., CHAPMAN, V.M., BESMER, P. AND BERNSTEIN, A. (1988). The proto-oncogene c-kit encoding a transmembrane tyrosine kinase receptor maps to the mouse W locus. Nature 335: 88-89.

COPELAND, N.G., GILBERT, D.J., CHO, B.C., DONOVAN, P.J., JENKINS, N.A., COSMAN, D. ANDERSON, D., LYMAN, S.D. AND WILLIAMS, D.E. (1990) Mast cell growth factor maps near the steel locus on mouse chromosome 10 and is deleted in a number of steel alleles. Cell 63: 175-183.

DEMUNTER,A., WOLF-PEETERS,C., DEGREEF,H., STAS,M. and VAN DEN OORD,J.J. (2001). Expression of the endothelin-B receptor in pigment cell lesions of the skin. Evidence for its role as tumor progression marker in malignant melanoma. Virchows Arch. 438: 485-491.

DIPPEL, E., HAAS, N., GRABBE, J., SCHADENDORF, D., HAMANN, K. AND CZARNETZKI, B.M. (1995). Expression of the c-kit receptor in hypomelanosis: a comparative study between piebaldism, naevus depigmentosus and vitiligo. Br. J. Dermatol. 132: 182-189.

DUPIN, E., GLAVIEUX, C., VAIGOT, P. and LE DOUARIN, N.M. (2000). Endothelin 3 induces the reversion of melanocytes to glia through a neural crest-derived glial-melanocytic progenitor. Proc. Natl. Acad. Sci. USA 97: 7882-7887.

DUPIN, E. and LE DOUARIN, N.M. (2003). Development of melanocyte precursors from the vertebrate neural crest. Oncogene 22: 3016-3023.

DUPIN, E., REAL, C., GLAVIEUX-PARDANAUD, C., VAIGOT, P. and LE DOUARIN, N.M. (2003). Reversal of developmental restrictions in neural crest lineages: transition from Schwann cells to glial-melanocytic precursors in vitro. Proc. Natl. Acad. Sci. USA 100: 5229-5233.

EZOE, K., HOLMES, S.A., HO, L., BENNETT, C.P., BOLOGNIA, J.L., BRUETON, L., BURN, J., FALABELLA, R., GATTO, E.M., ISHII, N. et al. (1995). Novel mutations and deletions of the KIT (steel factor receptor) gene in human piebaldism. Am. J. Hum. Genet. 56: 58-66.

FLEISCHMAN, R.A., SALTMAN, D.L., STASTNY, V. AND ZNEIMER, S. (1991). Deletion of the c-kit protooncogene in the human developmental defect piebald trait. Proc. Natl. Acad. Sci. USA 1988: 10885-10889.

GEISSLER, E.N., MCFARLAND, E.C. and RUSSELL, E.S. (1981). Analysis of pleiotropism at the dominant white-spotting (W) locus of the house mouse: a description of ten new W alleles. Genetics 97: 337-361.

GEISSLER, E.N., RYAN, M.A. and HOUSMAN, D.E. (1988). The dominant-white spotting (W) locus of the mouse encodes the c-kit proto-oncogene. Ce//55: 185192.

GORDON, J. (1977). Modification of pigmentation patterns in allophenic mice by the W gene. Differentiation 9: 19-27

HALABAN, R., CHENG, E., SMICUN, Y. and GERMINO, J. (2000). Deregulated E2F transcriptional activity in autonomously growing melanoma cells. J. Exp. Med. 191: 1005-1016.

HEMESATH, T.J., PRICE, E.R., TAKEMOTO, C., BADALIAN, T. and FISHER, D.E. (1998). MAP kinase links the transcription factor Microphthalmia to c-Kit signalling in melanocytes. Nature 391: 298-301.

HOSODA, K., HAMMER, R.E., RICHARDSON, J.A., BAYNASH, A.G., CHEUNG, J.C., GIAID, A. AND YANAGISAWA, M. (1994). Targeted and natural (piebald- lethal) mutations of endothelin-B receptor gene produce megacolon associated with spotted coat color in mice. Cel/ 79: 1267-1276.

HOU, L., PANTHIER, J.J. AND ARNHEITER, H. (2000). Signaling and transcriptional regulation in the neural crest-derived melanocyte lineage: interactions between KIT and MITF. Development 127: 5379-5389.

HSU, M.Y., MEIER, F.E., NESBIT, M., HSU, J.Y., VAN BELLE, P., ELDER, D.E. AND HERLYN, M. (2000). E-cadherin expression in melanoma cells restores keratinocyte-mediated growth control and down-regulates expression of invasionrelated adhesion receptors. Am. J. Pathol. 156: 1515-1525.

HUANG, E., NOCKA, K., BEIER, D.R., CHU, T.Y., BUCK, J., LAHM, H.W., WELLNER, D., LEDER, P. AND BESMER, P. (1990). The hematopoietic growth factor $\mathrm{KL}$ is encoded by the $\mathrm{SI}$ locus and is the ligand of the c-kit receptor, the gene product of the $W$ locus. Cel/ 63: 225-233.

IMOKAWA, G., YADA, Y. and MIYAGISHI, M. (1992). Endothelins secreted from human keratinocytes are intrinsic mitogens for human melanocytes. J. Biol. Chem. 267: 24675-24680.

ISHIKAWA, K., IHARA, M., NOGUCHI, K., MASE, T., MINO, N., SAEKI, T., FUKURODA, T., FUKAMI, T., OZAKI, S., NAGASE, T. et al. (1994). Biochemical and pharmacological profile of a potent and selective endothelin B-receptor antagonist, BQ-788. Proc. Natl. Acad. Sci. USA 91: 4892-4896.

JAMAL, S. and SCHNEIDER, R.J. (2002). UV-induction of keratinocyte endothelin1 downregulates E-cadherin in melanocytes and melanoma cells. J. Clin. Invest 110: 443-452.

LAHAV, R., LECOIN, L., ZILLER, C., NATAF, V., CARNAHAN, J.F., MARTIN, F.H. and LE DOUARIN, N.M. (1994). Effect of the Steel gene product on melanogenesis in avian neural crest cell cultures. Differentiation 58: 133-139.

LAHAV, R., ZILLER, C., DUPIN, E. and LE DOUARIN, N.M. (1996). Endothelin 3 promotes neural crest cell proliferation and mediates a vast increase in melanocyte number in culture. Proc. Natl. Acad. Sci. USA 93: 3892-3897.

LAHAV, R., DUPIN, E., LECOIN, L., GLAVIEUX, C., CHAMPEVAL, D., ZILLER, C. AND LE DOUARIN, N.M. (1998). Endothelin 3 selectively promotes survival and proliferation of neural crest-derived glial and melanocytic precursors in vitro. Proc. Natl. Acad. Sci. USA 95: 14214-14219.

LAHAV, R., HEFFNER, G. and PATTERSON, P.H. (1999). An endothelin receptor $\mathrm{B}$ antagonist inhibits growth and induces cell death in human melanoma cells in vitro and in vivo. Proc. Natl. Acad. Sci. USA 96: 11496-11500.

LAHAV, R., SUVÀ, M.L., RIMOLDI, D., PATTERSON, P.H. and STAMENKOCIV, I. (2004). Endothelin receptor B inhibition triggers apoptosis and enhances angiotenesis in melanomas. Cancer Res. 64: 8945-8953.

LASSAM, N. and BICKFORD, S. (1992). Loss of c-kit expression in cultured melanoma cells. Oncogene 7: 51-56.

LE DOUARIN, N.M. and KALCHEIM, C. (1999). The Neural Crest. Cambridge University Press).

LECOIN, L., LAHAV, R., MARTIN, F.H., TEILLET, M.A. and LE DOUARIN, N.M. (1995). Steel and c-kit in the development of avian melanocytes: a study of normally pigmented birds and of the hyperpigmented mutant silky fowl. Dev. Dyn. 203: 106-118.

LECOIN, L., SAKURAI, T., NGO, M.T., ABE, Y., YANAGISAWA, M. and LE DOUARIN, N.M. (1998). Cloning and characterization of a novel endothelin receptor subtype in the avian class. Proc. Natl. Acad. Sci. USA 95: 3024-3029.

LISTER, J.A., ROBERTSON, C.P., LEPAGE, T., JOHNSON, S.L. and RAIBLE, D.W. (1999). nacre encodes a zebrafish microphthalmia-related protein that regulates neural-crest-derived pigment cell fate. Development 126:3757-3767.

LITTLE CC (1915). The inheritance of black-eyed white spotting in mice. Amer. Nat. 49: 727 .

LOFTUS, S.K., CHEN, Y., GOODEN, G., RYAN, J.F., BIRZNIEKS, G., HILLIARD, M., BAXEVANIS, A.D., BITTNER, M., MELTZER, P., TRENT, J. and PAVAN,W (1999). Informatic selection of a neural crest-melanocyte cDNA set for microarray analysis. Proc. Natl. Acad. Sci. USA 1996: 9277-9280.

LUSCHER, T.F. and BARTON, M. (2000). Endothelins and endothelin receptor antagonists: therapeutic considerations for a novel class of cardiovascular drugs. Circulation 102: 2434-2440.

LYON, MF and SEARLE, AG (1990). Genetic variants and strains of the laboratory mouse. Oxford University Press).

MANOVA, K. and BACHVAROVA, R.F. (1991). Expression of c-kit encoded at the W locus of mice in developing embryonic germ cells and presumptive melanoblasts. Dev. Biol. 146: 312-324. 
MARKERT, CL and SILVERS, WK (1956). The effects of genotype and cell environment on melanoblast differentiation in the house mouse. Genetics 41: 429.

MARTIN, F.H., SUGGS, S.V., LANGLEY, K.E., LU,H.S., TING, J., OKINO, K.H., MORRIS, C.F., MCNIECE, I.K., JACOBSEN, F.W., MENDIAZ, E.A., et al. (1990). Primary structure and functional expression of rat and human stem cell factor DNAs. Cell 63: 203-211.

MAYER, T.C. (1970). A comparison of pigment cell development in albino, steel and dominant-spotting mutant mouse embryos. Dev. Biol. 23: 297-309.

MAYER,T.C. (1979). Interactions between normal and pigment cell populations mutant at the dominant-spotting $(\mathrm{W})$ and steel $(\mathrm{SI})$ loci in the mouse. J. Exp. Zool. 210: 81-88

McCALLION, A.S. and CHAKRAVARTI, A. (2001). EDNRB/EDN3 and Hirschsprung disease type II. Pigment Cell Res. 14: 161-169.

McGILL, G.G., HORSTMANN, M., WIDLUND, H.R., DU, J., MOTYCKOVA, G., NISHIMURA, E.K., LIN, Y.L., RAMASWAMY, S., AVERY, W., DING, H.F., JORDAN, S.A., JACKSON, I.J., KORSMEYER, S.J., GOLUB, T.R. AND FISHER, D.E. (2002). Bcl2 regulation by the melanocyte master regulator Mitf modulates lineage survival and melanoma cell viability. Cell 109: 707-718.

MINTZ, B. (1967). Gene control of mammalian pigmentary differentiation. I. Clonal origin of melanocytes. Proc. Natl. Acad. Sci. USA 58: 344-351.

MORRISON-GRAHAM, K. and WESTON, J.A. (1993). Transient steel factor dependence by neural crest-derived melanocyte precursors. Dev. Biol. 159: 346-352.

MURPHY, M., REID, K., WILLIAMS, D.E., LYMAN, S.D. AND BARTLETT, P.F. (1992). Steel factor is required for maintenance, but not differentiation, of melanocyte precursors in the neural crest. Dev. Biol. 153: 396-401.

NATAF, V., LECOIN, L., EICHMANN, A. AND LE DOUARIN, N.M. (1996). EndothelinB receptor is expressed by neural crest cells in the avian embryo. Proc. Natl. Acad. Sci. USA 93: 9645-9650.

NISHIKAWA, S., KUSAKABE, M., YOSHINAGA, K., OGAWA, M., HAYASHI, S. KUNISADA, T., ERA, T., SAKAKURA, T. AND NISHIKAWA, S. (1991). In utero manipulation of coat color formation by a monoclonal anti-c-kit antibody: two distinct waves of c-kit-dependency during melanocyte development. EMBOJ.10: 2111-2118.

NYORMOI, O. and BAR-ELI, M. (2003). Transcriptional regulation of metastasisrelated genes in human melanoma. Clin. Exp. Metastasis 20: 251-263.

PAVAN, W.J. and TILGHMAN, S.M. (1994). Piebald lethal (sI) acts early to disrupt the development of neural crest-derived melanocytes. Proc. Natt. Acad. Sci. USA 91: 7159-7163.

POTTERF, S.B., FURUMURA, M., DUNN, K.J., ARNHEITER, H. AND PAVAN, W.J. (2000). Transcription factor hierarchy in Waardenburg syndrome: regulation of MITF expression by SOX10 and PAX3. Hum. Genet. 107: 1-6.

PRICE, E.R., DING, H.F., BADALIAN, T., BHATTACHARYA, S., TAKEMOTO, C., YAO, T.P., HEMESATH, T.J. and FISHER, D.E. (1998). Lineage-specific signaling in melanocytes. C-kit stimulation recruits $\mathrm{p300/CBP}$ to microphthalmia. J. Biol. Chem. 273: 17983-17986.

PUFFENBERGER, E.G., HOSODA, K., WASHINGTON, S.S., NAKAO, K., DEWIT, D., YANAGISAWA, M. and CHAKRAVART, A. (1994). A missense mutation of the endothelin-B receptor gene in multigenic Hirschsprung's disease. Cell 79: 12571266.

RAWLS, J.F., MELLGREN, E.M. and JOHNSON, S.L. (2001). How the zebrafish gets its stripes. Dev. Biol. 240: 301-314.

REID, K., TURNLEY, A.M., MAXWELL, G.D., KURIHARA, Y., KURIHARA, H., BARTLETT, P.F. and MURPHY, M. (1996). Multiple roles for endothelin in melanocyte development: regulation of progenitor number and stimulation of differentiation. Development 122: 3911-3919.

ROSS, D.T., SCHERF, U., EISEN, M.B., PEROU, C.M., REES, C., SPELLMAN, P., IYER, V., JEFFREY, S.S., VANDE, R.M., WALTHAM, M., PERGAMENSCHIKOV, A., LEE, J.C., LASHKARI, D., SHALON, D., MYERS, T.G., WEINSTEIN, J.N., BOTSTEIN, D. and BROWN, P.O. (2000). Systematic variation in gene expression patterns in human cancer cell lines. Nat. Genet. 24: 227-235.

RUSSELL, E.S. (1979). Hereditary anemias of the mouse: a review for geneticists. Adv. Genet. 20: 357-459.

SAKURAI, T., YANAGISAWA, M., TAKUWA, Y., MIYAZAKI, H., KIMURA, S., GOTO, K. AND MASAKI, T. (1990). Cloning of a cDNA encoding a non-isopeptideselective subtype of the endothelin receptor. Nature 348: 732-735.
SARVELLA, P.A. and RUSSELL, L.B (1956). Steel, a new dominant gene in the house mouse. J. Hered. 47: 123.

SATO, S., ROBERTS, K., GAMBINO, G., COOK, A., KOUZARIDES, T. and GODING, C.R. (1997). CBP/p300 as a co-factor for the Microphthalmia transcription factor. Oncogene 14: 3083-3092.

SCHAIBLE, R.H. (1969). Clonal distribution of melanocytes in piebald-spotted and variegated mice. J. Exp. Zool. 172: 181-199.

SHIN, M.K., LEVORSE, J.M., INGRAM, R.S. and TILGHMAN, S.M. (1999). The temporal requirement for endothelin receptor-B signalling during neural crest development. Nature 402: 496-501.

SILVERS, W.K (1979). The coat colors of mice: A model for gene action and interaction. (New York: Springer Verlag).

SOUTHARD-SMITH, E.M., KOS, L. AND PAVAN, W.J. (1998). Sox10 mutation disrupts neural crest development in Dom Hirschsprung mouse model. Nat. Genet. 18: 60-64.

SPRITZ, R.A., GIEBEL, L.B. and HOLMES, S.A. (1992). Dominant negative and loss of function mutations of the c-kit (mast/stem cell growth factor receptor) protooncogene in human piebaldism. Am. J. Hum. Genet. 50: 261-269.

STEEL, K.P., DAVIDSON, D.R. and JACKSON, J. (1992). TRP-2/D, a new early melanoblast marker, shows that Steel growth factor (c-kit ligand) is a survival factor. Development. 115: 1111

STRACHAN, F.E., SPRATT, J.C., WILKINSON, I.B., JOHNSTON, N.R., GRAY, G.A. and WEBB, D.J. (1999). Systemic blockade of the endothelin-B receptor increases peripheral vascular resistance in healthy men. Hypertension 33: 581-585.

SVIDERSKAYA, E.V., EASTY, D.J. and BENNETT, D.C. (1998). Impaired growth and differentiation of diploid but not immortal melanoblasts from endothelin receptor $B$ mutant (piebald) mice. Dev. Dyn. 213: 452-463.

TACHIBANA, M., TAKEDA, K., NOBUKUNI, Y., URABE, K., LONG, J.E., MEYERS, K.A., AARONSON, S.A. and MIKI, T. (1996). Ectopic expression of MITF, a gene for Waardenburg syndrome type 2, converts fibroblasts to cells with melanocyte characteristics. Nat. Genet. 14: 50-54.

TEILLET, M.A. and LE DOUARIN, N. (1970). [The migration of pigmentary cells studies by the method of heterospecific grafts of neural tube in bird embryo]. C. $R$ Acad. Sci. Hebd. Seances Acad. Sci. D. 270: 3095-3098

WEEDON, D. (2002). Skin Pathology, second ed., Churchill Livingstone.

WEHRLE-HALLER, B. and WESTON, J.A. (1995). Soluble and cell-bound forms of steel factor activity play distinct roles in melanocyte precursor dispersal and survival on the lateral neural crest migration pathway. Development 121: 731742 .

WILLIAMS, D.E., EISENMAN, J., BAIRD, A., RAUCH, C., VAN NESS, K., MARCH, C.J., PARK, L.S., MARTIN, U., MOCHIZUKI, D.Y., BOSWELL, H.S., etal. (1990). Identification of a ligand for the c-kit proto-oncogene. Cell 63: 167-174

WU, M., HEMESATH, T.J., TAKEMOTO, C.M., HORSTMANN, M.A., WELLS, A.G., PRICE, E.R., FISHER, D.Z. and FISHER, D.E. (2000). c-Kit triggers dual phosphorylations, which couple activation and degradation of the essential melanocyte factor Mi. Genes Dev. 14: 301-312.

YANAGISAWA, M. (1994). The endothelin system. A new target for therapeutic intervention. Circulation 89: 1320-1322.

YOSHIDA, H., KUNISADA, T., GRIMM, T., NISHIMURA, E.K., NISHIOKA, E. and NISHIKAWA, S.I. (2001). Review: melanocyte migration and survival controlled by SCF/c-kit expression. J. Invest. Dermatol. Symp. Proc. 6: 1-5.

YOSHIDA, H., KUNISADA, T., KUSAKABE, M., NISHIKAWA, S. and NISHIKAWA, S.I. (1996). Distinct stages of melanocyte differentiation revealed by anlaysis of nonuniform pigmentation patterns. Development 122: 1207-1214.

ZAKUT, R., PERLIS, R., ELIYAHU, S., YARDEN, Y., GIVOL, D., LYMAN, S.D. AND HALABAN, R. (1993). KIT ligand (mast cell growth factor) inhibits the growth of KIT-expressing melanoma cells. Oncogene 8: 2221-2229.

ZHU, L., LEE, H-O., JORDAN, C.S., CANTRELL, V.A., SOUTHARD-SMITH, E. M. and SHIN, M.K. (2004). Spatiotemporal regulation of endothelin receptor-B by SOX10 in neural crest-derived enteric neuron precursors. Nature genetics 36 $732-737$.

ZSEBO, K.M., WILLIAMS, D.A., GEISSLER, E.N., BROUDY, V.C., MARTIN, F.H., ATKINS, H.L., HSU, R.Y., BIRKETT, N.C., OKINO, K.H., MURDOCK, D.C. et al. (1990). Stem cell factor is encoded at the SI locus of the mouse and is the ligand for the c-kit tyrosine kinase receptor. Cel/ 63: 213-224. 